\title{
Perspectives of Strengthening Primary and High School Teaching Practices in South Africa
}

\author{
Remy M.K. Vala \\ Department of Chemistry, Vaal University of Technology, P. O. Box X021, Vanderbijlpark 1900, \\ Republic of South Africa \\ Theo M. Talwanga* \\ Department of Mathematics, Central University of Technology, P.O Box 1881, Welkom 9460, South Africa \\ Email: mtalwanga@cut.ac.za
}

\section{Doi:10.5901/jesr.2015.v5n1p145}

\begin{abstract}
The profession of teaching is and should be considered as one of the most important in all countries. The reason is that any skill, be it technical or social, is acquired from teaching and learning process. Therefore, training teachers should be done with respect to profile of the person needed. In this article, we investigated some aspects of the South African education system with regard to faculties or colleges of education curriculum, teacher, micro-teaching lessons, and placement process. Based on the pillars underpinning the DR Congo education system, suggestions are made to strengthen the South African education system.
\end{abstract}

Keywords: Curriculum, Teacher, Micro-teaching lessons, Placement

\section{Introduction}

Teaching is a "Profession" as well as sometime an "Art". Like any other profession, teaching implies knowledge and skill acquired. A person wishing to become a teacher must first obtain specified professional qualifications or credentials from a university or college. These professional qualifications include "specific skill" and the study of "pedagogy". In this paper, we call "specific skill" the knowledge (English, French, Chemistry, Mathematics, Geography...) needed to be transferred by teachers to learners. Pedagogy empowers teachers with the method and practice of teaching, facilitating the learning process by understanding and responding to the learners need (Bobis, 2007; Khatib and Fat'hi, 2012). Sometimes, people mischievously correlated the profession of teaching to the fact of holding a degree. Consequently, it happen that teachers without pedagogy skill (although possessing their "specific skill") land up to a chaotic end of lessons or school output, even with learners disliking subjects of higher importance for life (Stuart and Tatto, 2000; Niemi, 2002). This means that a focus on teaching skill for teachers is of great importance because pedagogy (method and practice of teaching) provides useful skills, such as:

- The use of the blackboard (projector or screen);

- Movement and gestures of the teacher in the classroom;

- Focus behaviours (looking, listening...), interaction styles;

- Setting of objectives, questions and lesson plan to facilitate student learning;

- Understanding the level of learners and the flow of different lessons;

- Classroom management skill;

- Assessing, evaluating and setting of promotion criteria, etc.

Therefore, if one might, "by birth", have some pedagogy skill; it is well known that any skill is acquired from school. Nowadays, most schools (particularly the tertiary-education) have related the promotion of their staffs with pedagogy skill, beside other parameters. For example, from September 2001 new lecturers in the United Kingdom were required to gain a recognised teaching qualification (Blackstone, 2000; Crequer, 2000), making more professional the nature of learning and teaching. It is so in many South African universities. Questions, therefore, arise on the how and where to get pedagogy skill, especially for primary and high school teachers. These questions are of great importance because, the same way one cannot improvise to be a professional mechanic or electrician, and none should improvise to be a 
professional teacher. Different approaches can be used for improving the education system of a country, and we assume that a comparative study appears to be one of the better ways (Mbozi, 2010). Therefore, based on our teaching experience in both countries (DR Congo and South Africa), we decided to explore the approaches for strengthening the South African education system (primary and high school) by highlighting some pillars underpinning the Congolese system. We think that a deep analysis of the education system of the two countries would give a lot of insight although, over the years, many parameters have changed with the political instability in the DR Congo. If most papers provide a comprehensive description of the trends in policy effecting equity and quality of the South African education system, not much is said regarding the curricula (backbone of the education system), to the extent that some people (like Mamphela Ramphele, Agang SA leader, and Pik Botha, the South Africa's former apartheid foreign affairs minister) estimate that education system was better before the advent of democracy. Therefore, this paper is an analysis done as response to such criticism.

\section{Faculties and Colleges of Education}

The purpose of the faculties and colleges of education is to give specific skill and train directly into the teaching profession. In order to release qualify teachers, most institutions of education not only have a curriculum well equipped with subjects such as child and adult psychology, psycho-pedagogy and didactic, but a strong focus on practical skills that would better prepare learners for the labour market.

\subsection{Micro-teaching lesson}

Micro-teaching lesson was first introduced at Stanford University in 1963 (Sparks, 1969). It was reported (Allen, 1967) that the approach was designed as a scaled-down teaching encounter which should serve 3 purposes: (1) as preliminary experience and practice in teaching, (2) as a research vehicle to explore training effects under controlled conditions, and (3) as an in-service training instrument for experienced teachers. During the micro-teaching lesson, the trainees were exposed to variables in classroom teaching without being overwhelmed by the complexity of the situation. To give them an opportunity of practicing certain technical skills, trainees were required to teach brief lessons (5 to 25 minutes) in their teaching subject, to a small group of pupils (up to 5). Foster (1967) and Baird et al. (1967) stated that by teaching, observing, and reteaching, trainees were making significant changes in their teaching techniques and they became aware of the acts they will perform and acquired the ability to analyse these acts, thus enabling them to perform in a better way. Improvement is made after finding out what has worked, which aspects have fallen short, and what needs to be done to enhance their teaching technique through evaluation, criticism, and advices from oneself, peers, mentor, and supervisor.

Depending on the country and school, many faculties and colleges of education have adopted to organize microteaching lessons for their trainee teachers in specific schools which serve as laboratories to boost their teaching skill (Avis et al., 2002).

\subsection{Placement of the trainee teachers}

Learning to teach is a complex endeavour and satisfaction comes in more field-based experiences added to teacher education programs (Femhdez, 2012). It has been reported (Lortie, 1975; Stones, 1987) that participation in field-based experiences and personal observations of practice often serve to socialize teachers into the status quo. Therefore, to gain field experiences and reduce the idiosyncratic nature of prospective teacher preparation, it is suitable to expose prospective teachers to consecutive teaching tasks and environments that will help them more develop their teaching skill; and Coll et al. (2002) to remind that practicum is seen as a vital part of teacher training worldwide. Therefore, placements are vital to teachers. Depending on how schools and educational establishments operate, placements are scheduled for three or six months, even for a full year. During that period, the trainee teachers receive feedback from their mentors and the supervisor send by the faculty or college of education who periodically circulate to visit the trainee teachers and ensure good progress of the placement. Then, mentors produce mid- or end-of-practice reports on the trainee teacher, and these, together with input from the faculty supervisor, determine whether students have achieved a satisfactory outcome to their practicum. 


\section{Case Studies}

\subsection{The DR Congo education system}

As said previously, many parameters have changed with the political instability in the DRC lowering its education system; however, some pillars underpinning the education system of this country can be used to rethink that of South Africa in the way teachers are trained for acquiring the teaching skill. Similar to that of Belgium, the general educational system in the DRC is organised as follows: pre-school or Kindergarten (2 years, generally in Urban area, not compulsory) and the primary education last for 6 years. A Certificate of Primary Education gives access to secondary education. The secondary education is either the "Short cycle" (technical education) or "Long cycle" (general and technical education) and last for 5 and 6 years, respectively. In the two first years of secondary education (junior secondary, formerly called orientation cycle), common to short and long cycles, learners study general subjects which, at the end, prepare them to decide (from their performances and ambitions) what they intend to study in the future. Only those who have completed and passed the Long cycle (Diplôme d'Etat) are eligible for admission to higher education (Banque mondiale, 2005).

In that environment, teachers are required to have a thorough knowledge of their "specific skill" and have been forced to attend and pass pedagogical subjects such as, general psychology, child and adult psychology, psychopedagogy and didactics, before completing their qualification. Otherwise, the teacher is called "Unqualified teacher". No unqualified teacher is accepted in primary education even though it happens in secondary education (because one might have "specific skill" without pedagogy training). The importance of pedagogical training is based on the reported assumption (Foster, 2000) that many external factors affect the learning process, and these factors have to be taken into account when teaching, to highly improve the learning process.

\subsubsection{Qualification for teaching at primary school level}

The skill of teaching in primary school is acquired at secondary (high) school where a specific curriculum is set for that purpose. With a curriculum including Chemistry (from grade 9 to 11), Mathematics, Biology, French, Physics, Geography, History, Music, Drawing and other subjects like philosophy (only at grade 12), students who choose to undertake the Pedagogy section (leading to become a primary school teacher) start attending primary-school classes as assistants during the second semester of their grade 10 (fourth year after primary education). In grade 11, students have to commence their micro teaching lessons and in grade 12 (final year, Long cycle) they spend six months during the placement period (compulsory) in a primary school as trainee teachers.

\subsubsection{Qualification for teaching at secondary school level}

Becoming a teacher in secondary school implies attending an "Institut Supérieur Pédagogique (ISP)" or an "Institut Supérieur Pédagogique Technique (ISPT)", which literally are "High Pedagogical Institute" and "Technical High Pedagogical Institute", respectively. Essentially established (in 1961 and 1964) (Mopondi, 2009) to train teachers, students registered in these institutions for an academic discipline (Physics, Mathematics, Biology, Electrical Angering, Electronics...) are empowered with pedagogical modules (as explained above) and a strong emphasize on the teaching ("special didactic") of those subject. These institutions either have their own secondary school (IDAP = Institut d'Application, or EDAP = Ecole d'Application) or target specific one for practica. People employed in these secondary schools are entirely staff (even lectures) of the faculty or college of education. Some universities (or faculties) organize an Agrégation (teaching courses) for students desiring to become secondary school teachers whereas the main goal of their institution is not to train teachers. Some examples of secondary schools where micro-teaching lessons are conducted are: College Mont Amba for the Université de Kinshasa, IDAP of Université Pédagogique Nationale, and IDAP of Institut Supérieur Pédagogique of Lubumbashi, EDAP of Institut Supérieur de Bukavu. The identified school for practica is considered as the suited place for micro-teaching lessons, where all the teaching skills are practically acquired. The school mentor, lecturer from the faculty or college of education and peers trainee teachers assist one trainee teacher during his micro-teaching lesson. The presence of the "assistants" permits a balanced criticism after the lesson by evoking/mentioning short comings as well as strong points. Although they are used as laboratories, these secondary schools score the best results at the state national examination (Examen d'Etat) because, unlike what is reported for UK and New Zealand (pass/fail system, Coll et al., 2002), the grading (marking) system of the practica urge the trainee teachers, even the mentor, to compete to be the best one. 
It is noteworthy to mention that in the early years after the independence, in each and every province of the DRC was implemented a college of education to supply the need of teachers in the country. Different reforms in the education system of the country led to transform the colleges of education (Ecole de Régence, providing a "crash course" of managers and qualified teachers) to Ecole Pédagogique, later to Ecole Normale Moyenne, and then to Institut Supérieur Pédagogique (USAID, 1974; Mopondi, 2009; http://www.upn.ac.cd/upn/index.php?page=upn). The last, Institut Supérieur Pédagogique, has a curriculum that gives to their graduate students the possibility to pursue their studies to the doctorate level if they desire.

\subsection{Education system of South African}

The South African education system after apartheid has experienced almost radical reforms (since 1994) with a curriculum project called Curriculum 2005 (Jansen, 1998; Jansen and Taylor, 2003; Fiske and Ladd, 2004), structured in the form of learner-centered education which placed the teacher in the role of facilitator. This was a logical response against the Bantu education system established during the apartheid system. Although some institution were established but, these so-called 'bush' Universities (Fort Hare, Vista, Venda, and Western Cape) and colleges of education during the apartheid system were set with a curriculum unable to provide well trained African labour force to compete with white. This was a result of lack of teachers, and many of those who did teach were underqualified (http://www.sahistory.org.za/ topic/bantu-education-policy, Fiske and Ladd, 2004). Instead of reinforcing the colleges of education (established during the apartheid time), the new government decided to shut them down and only universities were allowed to train teachers in their faculties of education where students register for a specific discipline and are taught pedagogy. It appears (from our observation) that the curriculum of the specific subject (mathematics, physics, chemistry...) is very close (if not equivalent) to that of high school, to the extent that some teachers themself are somehow limited, unable to root their science in learners. Consequently, when receiving students for the first time in other faculties at universities, some lecturers are sometimes embarrassed in introducing new chapters in their classes.

Many faculties and colleges of education have designed good placement program for their trainee teachers and surely have established good relationship with the placement schools; however, questions arise on the responsibilities of mentors towards the university, the legal implications of both parties (university and the placement school), the contractual obligation of the mentor and the school towards the university and the trainee teacher in case this trainee teacher signs a contract stipulating his/her obligations towards the school. For the last concern, the question is, what happen to the trainee teacher if, during that period, the mentor resigns from the school?

As for the micro-teaching lessons, the process is common to many institutions whereby a trainee teacher uses his peers to learn and improve his teaching skill. Using peers trainee teachers as "pupils" should only be considered as a simulation of the real situation but not be used throughout. Unfortunately, it appears that some institutions have adopted the simulation as a permanent feature of their pedagogical training programs, thus truncating and twisting the system. Truncated and twisted because none should consider answers given or questions posed by peers as baseline to objectively improve the teaching skill. Peers are co-equals with almost the same knowledge. Also, their behaviour in class is different and should not be compared to that of teenagers or kids.

\subsubsection{Some solutions so far}

Being aware of the challenges encountered by the education system, the South Africa government is investing about $7 \%$ of gross domestic product (GDP) and 20\% of total state expenditure to the extent that the country has the highest rates of public investment in education in the world (http://www.southafrica.info/about/education/education.htm, Kearney and Odusola, 2011). Also, the Department of Education endeavours to improve the system by many other strategies which are envisaged to take the challenge, such as the re-opening of some former teacher training colleges (http://www.southafrica.info/about/education/teachers-250412.htm) and intensification of workshop-training for high school teachers. For example, in 2008 the Department of Basic Education organized a workshop-training (every Saturday from February to November) for grade twelve Mathematics and Physical Sciences teachers from Dinaledi schools in the Eastern Cape (training centres: District Office in Fort Beaufort and Nathanael Nyaluza High School in Grahamstown). Unfortunately, very little was said concerning the didactical aspects of the teaching profession during this workshop-training which intended to improve the teachers' knowledge with regard to the National Curriculum Statement (NCS). Although the organisers assumed that teachers were experienced to easily apply the new knowledge. From our own experience on the ground, however, the workshop-training left attendees with the gape unfilled. Conducted by peer 
teachers, the training project did not have any follow-up to determine its success, the only measuring tape being, as usual, the matric passing rate in the subject.

\section{Suggestions and Recommendations}

To the best of our knowledge, we think that improvement of the education system should be a process involving not only the Department of Education as decision maker but also, Universities and Colleges of education as well as teachers who have to implement all the strategies. Therefore, experience acquired from any part of the world should be somehow considered for that purpose. Thus, based on the education systems described above, it appears useful to suggest the following:

\subsection{Reinforcement of faculties and colleges of education}

If owning a high school like in the case of IDAP/EDAP, mentioned above is not possible, then the faculties or colleges of education should dispatch a pool of relevant personnel and expertise to the placement schools as for trainee teachers. The faculties or colleges of education and the Department of basic education should make some arrangements on how a mentorship has to be conducted between the school teacher and the trainee teacher.

\subsection{Micro-teaching lesson}

Using peers as pupils should only be a simulation of the real case and should not be used throughout, because peers trainee teachers do not have the same apprehension and behaviour in the classroom as secondary school learners. Therefore, it is difficult to lean on such practice and expect to have acquired the appropriate teaching skills. This practice should be used as a temporary arrangement, not be adopted as a permanent feature of pedagogical training programmes. The school for practica, being a laboratory, should be a place where researchers in education would familiarised with new projects, like when the NCS was first introduced (reference). An identified school for practical should be the best suited place for micro-teaching lessons, using actual pupils in class. In such circumstances, lecturers in charge, the mentor from the school, and peers trainee teachers are observers.

\subsection{Trainee teachers placement}

The aforementioned scenario warrants the following recommendations:

- The faculties/college of education as Institutions of teacher training should work with the Department of Education to develop and adopt certain schools as placement centres for their trainees teacher;

- The faculties/college of education and the placement school for practical should devise a joint pedagogical program informed by the education philosophy of the training Institutions.

\section{Conclusion}

Based on the literature review and a comparative education principle, this study had suggested ways to strengthening the South African education system. A rethinking focused on the curriculum and training of trainee teachers of primary and secondary school level and the different processes used to acquire the teaching skills are major pillars that should underpin the South African education system. In addition, emphasized on the necessity of sufficiently exposing teachers to the field work experience by means of well-designed micro-teaching lessons and placement system.

\section{References}

Bobis J. (2007) Empowered to Teach: A Practice-based Model of Teacher Education, Proceedings of the 30th annual conference of the Mathematics Education Research Group of Australasia J. Watson \& K. Beswick (Eds), MERGA Inc., 61-70

Khatib M. and Fat'hi J. (2012) Postmethod Pedagogy and ELT Teachers, Journal of Academic and Applied Studies, 2(2), 22- 29

Stuart J.S. and Tatto M.T. (2000) Designs for initial teacher preparation programs: an international view, International Journal of Educational Research, 33(5), 493-514

Niemi H. (2002) Active learning - a cultural change needed in teacher education and schools, Teaching and Teacher Education, 18(7), 763-780 
Blackstone, T. (2000) Speech to the FEFC Annual General Meeting and Principals Conference in Birmingham, 2 November. Source: http://www.fento.co.uk/start.html (05-06-2014).

Crequer, N. (2000) All new chiefs to undergo training, Times Educational Supplement, p. 33.

Emmy H. Mbozi (2010) Comparative education, http://www.out.ac.tz/avu/images/Education/COMPARATIVE-EDUCATION.pdf Google book (07-06-2014)

Sparks R.L. (1969) The effect of micro-teaching laboratory experiences On attitudes and verbal behavior of Pre-serv" ice elementary School teachers, PhD Theses, North Texas State University, USA

Allen, Dwight W. (1967) Micro-teaching, A Description, Report, Stanford University, California, http://files.eric.ed.gov/fulltext/ED01 9224.pdf (02-05-2014)

Foster F.G. (1967) "Micro-Teaching," Arizona Teacher, 55, 12-13

Baird J.H. and others (1967) "Micro-Teaching at Brigham Young University," ERIC ED Oil 260.

Avis J., Bathmaker A.-M. and Parsons J. (2002) "I think a Lot of Staff are Dinosaurs": further education trainee teachers' understandings of pedagogic relations, Journal of Education and Work, 15(2), 181-200.

Femhdez M.L. (2012) Learning Through Micro teaching Lesson Study in Teacher Preparation, Action in Teacher Eductaion, 26(4), 3747.

Lortie, D. (1975) Schoolteacher: A sociological study. Chicago: University of Chicago Press

Edgar Stones (1987) Teaching Practice Supervision: bridge between theory and practice, European Journal of Teacher Education, 10(1), 67-79

Coll R.K., Taylor N. and Grainger S. (2002) Assessment of Work Based Learning: Some Lessons from the Teaching Profession, AsiaPacific Journal of Cooperative Education, 3(2), 5-12

Banque mondiale: Département du développement humain- Région Afrique (2005) Le système éducatif de la République Démocratique du Congo: Priorités et alternatives http://siteresources.worldbank.org/INTAFRREGTOPEDUCATION/Resources/4446591210786813450/ED_CSR_DRCongo_fr.pdf (11-06-2014)

Foster R. (2000) Becoming a Secondary Teacher in France: a trainee perspective on recent developments in initial teacher training, Educational Studies, 26(1), 5-17

USAID (1974) The reorganization of higher education in Zaire, http://pdf.usaid.gov/pdf_docs/PNAAC493.pdf (12-06-2014)

Mopondi B.M. (2009) Des objectifs de l'enseignement à la formation des enseignants en République Démocratique du Congo http://www.congoforum.be/upldocs/L\%20ENSEIGNEMENT\%20EN\%20RDC\%20SELON\%20LE\%20PROF\%20MOPONDI.pdf (10-05-2014) http://www.upn.ac.cd/upn/index.php?page=upn

Jansen J.D. (1998) Curriculum Reform in South Africa: a critical analysis of outcomes-based education, Cambridge Journal of Education, 28(3), 321-331

Jonathan Jansen and Nick Taylor (2003) Educational Change in South Africa 1994-2003: Case Studies in Large-Scale Education Reform, Country Studies Education Reform and Management Publication Series, Vol. II, Nº1, World Bank report http://www.jet.org.za/publications/research/jansen-and-taylor-world-bank-report.pdf

Fiske E.B. and Ladd H.F. (2004) Elusive Equity: Education Reform in Post-apartheid South Africa, Donnelley and Harrisonburg, VirginiaUSA, Google book

http://www.sahistory.org.za/topic/bantu-education-policy (10-05-2014)

http://www.southafrica.info/about/education/education.htm (10-05-2014)

Kearney M. and Odusola A. (2011) Realizing the Millennium Development Goals through socially inclusive macroeconomic policies: Assessing Development Strategies to Achieve the MDGs in The Republic of South Africa, United Nations Department for Social and Economic Affairs http://www.southafrica.info/about/education/teachers-250412.htm (10-05-2014)

Bonnet G. (1996) La formation initiale des enseignants du premier et du second degré dans les I.U.F.M: présentation et problématique cinq ans après la création des IUFM, Les Dossiers d'Education et Formation, 46, 155-174. 